Sains Malaysiana 50(3)(2021): 735-742

http://dx.doi.org/10.17576/jsm-2021-5003-15

\title{
Evaluation of Chitin as a Biomarker of Pathogenic Fungal Isolates
}

(Penilaian Kitin sebagai Biopenanda Pencilan Kulat Patogen)

\author{
Ahmad Shehab Ahmad Lafi, Jacinta Santhanam*, TZar Mohd Nizam Khaithir, Nur Fashya Musa\& \\ FAHRUL HUYOP
}

\begin{abstract}
Chitin is a polysaccharide component of the inner cell wall of fungi that has been used to estimate fungal invasion in plant products. However, its detection in major pathogenic fungal species has not been investigated. The present study aimed to determine the chitin contents of pathogenic fungal species in order to evaluate its diagnostic potential as a biomarker for fungal infections. High performance liquid chromatography (HPLC) was used to measure chitin content. Pure chitin was acid hydrolyzed and the fluorescence of 9-fluorenylmethylchloroformate (FMOC-CI) derivatives of glucosamine produced were measured. The chitin contents of ten pathogenic fungal isolates were determined per mycelial dry weight. They varied from $18.61( \pm 0.09)$ to $47.12( \pm 0.50) \mu \mathrm{g} / \mathrm{mg}$ dry mycelial weight. Candida albicans and Cryptococcus neoformans exhibited the highest and lowest levels of chitin, respectively. Based upon relative amounts of chitin produced, three groups namely: high (Candida albicans, Cryptococcus gattii, Aspergillus niger and Penicillium at 47.12, 46.98, 46.05, and 44.15 $\mathrm{g} / \mathrm{mg}$ respectively), medium (Rhizopus, Aspergillus fumigatus, Fusarium solani, and Mucor at 36.61, 36.30, 35.03, and $34.84 \mu \mathrm{g} / \mathrm{mg}$, respectively), and low (Candida tropicalis and Cryptococcus neoformans at 20.78 and $18.61 \mu \mathrm{g} / \mathrm{mg}$, respectively), were identified. Chitin was not detectable in bacterial isolates used as controls. The chitin detection method offers a sensitive and specific tool for the quantification of chitin in pathogenic fungal isolates. The detection of chitin may be a useful assay for the diagnosis of fungal infections in clinical samples.
\end{abstract}

Keywords: Biomarker; chitin; diagnosis; HPLC; pathogenic fungi

\section{ABSTRAK}

Kitin adalah komponen polisakarida pada dinding sebelah dalam kulat yang telah digunakan untuk menentukan kehadiran kulat pada hasil tumbuhan. Walau bagaimanapun, pengesanan kitin dalam kulat patogen yang utama belum lagi dikaji. Kajian ini bertujuan menentukan kandungan kitin dalam spesies kulat patogen untuk menilai potensi diagnostiknya sebagai biopenanda jangkitan kulat. Kaedah kromatografi cecair prestasi tinggi (HPLC) telah digunakan untuk mengukur kandungan kitin. Hidrolisasi asid dilakukan terhadap kitin tulen untuk menghasilkan terbitan glukosamin 9-fluorenilmetilkloroformat (FMOC-CI) yang berpendafluor, lalu diukur. Kandungan kitin bagi sepuluh pencilan kulat patogen ditentukan berdasarkan berat kering miselia. Hasil yang diperoleh adalah dalam julat $18.61( \pm 0.09) \mathrm{ke} 47.12$ ( \pm 0.50) $\mu \mathrm{g} / \mathrm{mg}$ berat kering miselia. Kandungan tertinggi kitin terdapat pada Candida albicans manakala kandungan yang paling rendah pada Cryptococcus neoformans. Berdasarkan kandungan relatif kitin, tiga kumpulan dikenal pasti, iaitu tinggi (Candida albicans, Cryptococcus gattii, Aspergillus niger dan Penicillium dengan 47.12, 46.98, 46.05 dan $44.15 \mu \mathrm{g} / \mathrm{mg}$ masing-masing), sederhana (Rhizopus, Aspergillus fumigatus, Fusarium solani dan Mucor dengan 36.61, 36.30, 35.03 dan $34.84 \mu \mathrm{g} / \mathrm{mg}$ masing-masing) dan rendah (Candida tropicalis dan Cryptococcus neoformans dengan 20.78 dan $18.61 \mu \mathrm{g} / \mathrm{mg}$ masing-masing). Kitin tidak dapat dikesan pada pencilan bakteria yang diguna sebagai kawalan. Kaedah pengesanan kitin boleh digunakan sebagai suatu alat khusus dan sensitif untuk kuantifikasi kitin pada pencilan kulat patogen. Pengesanan kitin merupakan suatu asai yang mungkin berguna untuk diagnosis jangkitan kulat dalam sampel klinikal.

Kata kunci: Biopenanda; diagnosis; HPLC; kitin; kulat patogen

\section{INTRODUCTION}

The cell wall of fungi contains chitin which is a polysaccharide comprising monomers of $\mathrm{N}$-acetylglucosamine (Latge 2007). Chitin is very abundant in nature and is found as structural components not only in fungi but also in arthropods such as insects, crustaceans, cephalopods, and mollusks (Tharanathan \& Kittur 2003) but is not present in any known bacteria (Kim 2013). Hence, the presence of chitin in food or raw material (other than sea food that contains crustaceans such as crabs, lobsters, and shrimp) 
can indicate fungal contamination and this could be further quantified.

Currently, the most effective assay for chitin is by the method of Ride and Drysdale (1972). This assay is slow and complex, requiring up to $5 \mathrm{~h}$ to complete and is based on a colour reaction. The sensitivity of the assay is improved by using o-phthalaldehyde for producing glucosamine derivatives, after which high performance liquid chromatography (HPLC) is used to separate the products and finally detection of the fluorescent compounds is done using a spectrofluorimeter (Lin \& Cousin 1985). A similar HPLC method as described by Ekblad and Nasholm (1996) measured another fluorescent glucosamine derivative which contains 9-fluorenylmethylchloroformate.

A review of the literature showed the application of the chitin assay to estimate the extent of fungal invasion in various foods such as barley, wheat, soybeans and corn (Donald \& Mirocha 1977; Nandi 1978; Whipps \& Lewis 1980). The chitin assay was also used to measure the presence of pathogenic fungi and mycorrhizal fungi in soil (Ekblad \& Nasholm 1996; Ekblad et al. 1998; Penman et al. 2000) and to measure wood rotting fungi (Nilsson \& Bjurman 1998).

Although the detection of chitin has been widely utilized to determine fungal presence in various sources, thus far, the chitin assay has not been specifically used to detect pathogenic fungi in clinical samples. There is a need for this application of the chitin assay due to the increasing number of opportunistic fungal infections in immunocompromised patients. Immunocompromised patients are mainly individuals who are AIDS sufferers, organ or blood transplant recipients, cancer patients on chemotherapy and also others on immunosuppresive treatments (Brakhage 2005; Pfaller \& Diekema 2004). As such, invasive fungal infections have become a growing concern among the various medical fields such as intensive care medicine, hematology, and oncology (Vallabhaneni et al. 2016). However, only a small number of fungal species are actually responsible for causing systemic infections in humans. These pathogenic fungi can be grouped into yeasts and filamentous fungi. Common human pathogenic yeasts are Candida albicans, Candida glabrata, Candida krusei, Candida tropicalis, Trichosporon sp. and Cryptococcus spp. Pathogenic filamentous fungi include Aspergillus fumigatus, Aspergillus spp., Mucor, Rhizopus, and Fusarium. Some dematiaceous hyphomycetes are also known to be pathogenic to humans (Richardson 2005).

In this study, chitin was evaluated in pathogenic fungal isolates to determine its usefulness as a potential biomarker of fungal infection in clinical samples.

\section{MATERIALS AND METHODS}

Fungi: In this study, 10 pathogenic fungal isolates from clinical samples or laboratory stock cultures were selected for testing, namely: Ascomycota fungi: Aspergillus fumigatus, Aspergillus niger, Candida albicans, Candida tropicalis, Penicillium sp., and Fusarium solani; Basidiomycota fungi: Cryptococcus gattii, and Cryptococcus neoformans; Zygomycota fungi: Mucor sp. and Rhizopus sp. All of the fungal isolates were maintained on sterile $1.5 \%(\mathrm{w} / \mathrm{v})$ potato dextrose agar (PDA) slants and then used to inoculate sterile PDA plates which were incubated for 7 days. After 7 days of incubation, $5 \mathrm{~mm}^{2}$ pieces of the agar from the actively growing edge of the mycelial colonies were aseptically cut and used to inoculate $1 \mathrm{~L}$ flasks containing $500 \mathrm{~mL}$ of sterile potato dextrose broth (PDB). The flask cultures were incubated for 7 days on a rotary shaker at $125 \mathrm{rpm}$ at 37 ${ }^{\circ} \mathrm{C}$. To harvest the mycelial growth, the flask contents were filtered through cheesecloth to trap the mycelia which were further washed 3 times with $100 \mathrm{~mL}$ of sterile de-ionized water. The harvested mycelia was freeze-dried and then stored in clean capped sample bottles in a dessicator until further use.

Bacteria: Nutrient agar was used to subculture 4 bacterial isolates, namely: Staphylococcus aureus, Pseudomonas aeruginosa, Bacillus subtilis, and Escherichia coli. They were then used to inoculate 500 $\mathrm{mL}$ flasks containing $250 \mathrm{~mL}$ nutrient broth which were then incubated on a rotary shaker at $125 \mathrm{rpm}, 37{ }^{\circ} \mathrm{C}$ for 2 days. After this incubation, the bacterial biomass was harvested and freeze-dried before being stored in clean capped sample bottles in a dessicator until further use.

Sample preparation: Commercially produced pure chitin of shrimp origin (Sigma, C9752) was used as the chitin standard (0 to $1.5 \mathrm{mg}$ ). In order to remove extraneous proteins and amino acids from the samples, $1.0 \mathrm{~mL}$ of $0.2 \mathrm{~N} \mathrm{NaOH}$ was used to treat $100 \mathrm{mg}$ of freeze-dried samples (fungi or bacteria) in $1.5 \mathrm{~mL}$ screw-capped microcentrifuge tubes for $6 \mathrm{~h}$ at $20^{\circ} \mathrm{C}$. This was followed by a further $17.5 \mathrm{~h}$ of incubation in fresh $0.2 \mathrm{~N} \mathrm{NaOH}$ at a higher temperature of $100^{\circ} \mathrm{C}$. After the second incubation, the samples were washed 4 times in distilled water by resuspension and pelleting via centrifugation and were free of contaminants that could interfere with the glucosamine in the HPLC step. The $\mathrm{NaOH}$-treated samples were then acid hydrolized using $1.0 \mathrm{~mL}$ of $6 \mathrm{~N}$ hydrochloric acid (HCL) in $1.5 \mathrm{~mL}$ screw-capped microcentrifuge tubes at $100{ }^{\circ} \mathrm{C}$ (Ekblad \& Nasholm 1996). The optimal length of hydrolysis time was determined earlier to be $7 \mathrm{~h}$ (data not shown) and this was used as the standard procedure in this study. 
HPLC-determination of Chitin: To produce a fluorescent product, standard chitin or hydrolyzed samples from the previous step was converted to 9-fluorenylmethylchloroformate (FMOC-C1) derivatives. Briefly, $40 \mu \mathrm{L}$ of acid hydrolysate was first evaporated under reduced pressure before being dissolved in 800 $\mu \mathrm{L}$ of $5 \mu \mathrm{M}$ homocysteic acid, the latter also serving as internal standard. An aliquot of this solution $(200 \mu \mathrm{L})$ was pipetted into a $1.5 \mathrm{~mL}$ microcentrifuge tube containing $50 \mu \mathrm{L}$ of $1 \mathrm{M}$ borate buffer ( $\mathrm{pH}$ 6.3). To start the reaction, $250 \mu \mathrm{L}$ of $15 \mathrm{mM}$ FMOC-C1 (in acetone) was added followed by incubation at $10 \mathrm{~min}$ at room temperature. $\mathrm{n}$-heptane $(1 \mathrm{~mL})$ was then used to partition the sample and remove excess reagents by discarding the upper n-heptane phase while retaining the lower phase which contained the FMOC-glucosamine derivatives for HPLC analysis. Reversed-phase HPLC was performed using a waters liquid chromatography system equipped with a 600E pump, WISP 700 auto-injector and a workstation installed with the Empower 3 software to collect and analyze the data. A reversed-phase $250 \mathrm{~mm} \times 5 \mathrm{~mm}$ (I.D.) ODS-Hypersil $(5 \mu \mathrm{m})$ column was used. The HPLC conditions were as follows: initial $10 \mathrm{~min}$ of $1 \mathrm{~mL} / \mathrm{min}$ flow rate of elution in 40 to $50 \%$ gradient of methanol in buffer $(8 \mathrm{~mL}$ acetic acid, $1 \mathrm{~mL}$ triethylamine to $1 \mathrm{~L}$ water, $\mathrm{pH}$ adjusted to 4.2 with $\mathrm{NaOH}) ; 10$ min of a second isocratic phase; 10 min of a third phase of elution in 50 to $68 \%$ methanol; and a final 10 min of elution in 68 to $90 \%$ methanol. The eluents flowed through a Waters 2475 fluorescence detector (excitation $260 \mathrm{~nm}$, emission $330 \mathrm{~nm}$ ).

\section{RESULTS AND DISCUSSION}

The detection of chitin in different taxa of pathogenic fungi was evaluated in this study by using HPLC. The amount of chitin in each sample was quantified by comparing the HPLC chromatogram with the chitin standard. Chromatograms of chitin standard showed two peaks with retention times between 1.2 and $2 \mathrm{~min}$. The calibration curve of HPLC peak area for the chitin standard was linear with the values of 2894555, 2703874, 2469531, and 2185492 over the chitin amounts of 100, 50, 20, and 10 $\mathrm{mg}$, respectively (Figure 1, Table 1). The linear increase in HPLC peak area according to chitin amount present in the sample indicates that the chitin extraction method utilized in this study is reliable, enabling accurate measurement of chitin concentration in a given sample. Therefore, the calibration curve was used to calculate the chitin content of fungal and bacterial samples. The calibration curve range in this study is broader and at a higher range $(10-100 \mathrm{mg})$ compared to a previous study by Ekblad and Nasholm (1996) who obtained a linear calibration range of $0-0.3$ $\mathrm{mg}$ for hydrolyzed chitin, hence our results show that 9-fluorenylmethylchloroformate (FMOC-C1) glucosamine derivatives are reliable indicators of chitin presence even at high sample concentrations.

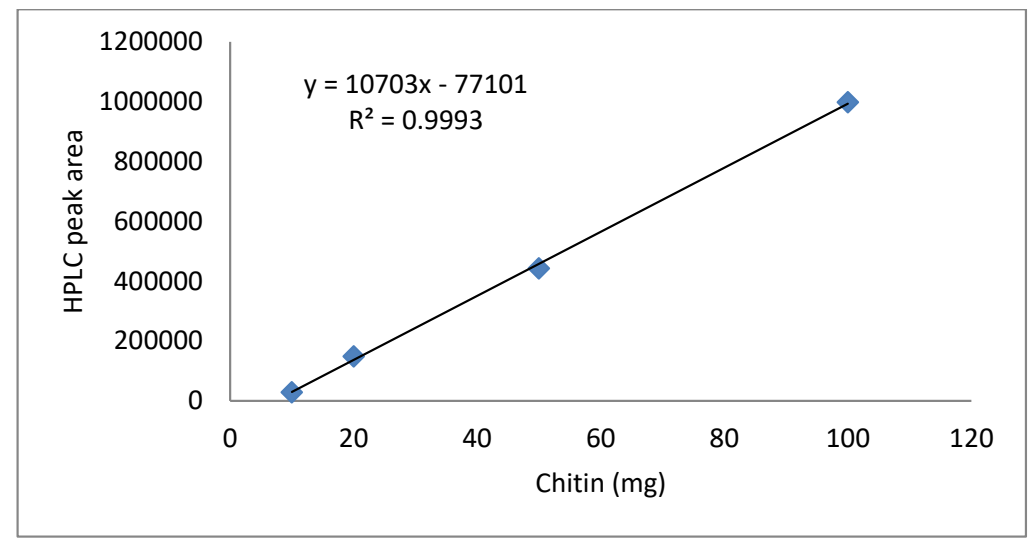

FIGURE 1. Calibration curve of chitin standard

TABLE 1. HPLC results of chitin standard

\begin{tabular}{cccc}
\hline Chitin (mg) & HPLC RT (minutes) & HPLC peak area & HPLC peak height \\
\hline 100 & 1.12 & 998621 & 2894555 \\
50 & 1.12 & 443099 & 2703874 \\
20 & 1.12 & 148212 & 2469531 \\
10 & 1.12 & 28245 & 2185492 \\
\hline
\end{tabular}

$\mathrm{RT}=$ retention time 
The chitin contents of ten pathogenic fungal isolates are shown in Table 2 and Figure 2. The chitin content varied from $18.61( \pm 0.09)$ to $47.12( \pm 0.50)(\mu \mathrm{g} / \mathrm{mg}$ dry mycelial weight). In our tests, $C$. neoformans showed the highest level of chitin while $C$. albicans exhibited the lowest chitin level.

TABLE 2. Chitin content of fungal and bacterial isolates determined by HPLC

\begin{tabular}{|c|c|c|c|c|c|c|}
\hline $\begin{array}{c}\text { Sample } \\
\text { no. }\end{array}$ & Sample & HPLC result & 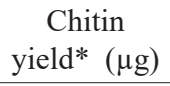 & $\begin{array}{l}\text { HPLC RT } \\
\text { (minutes) }\end{array}$ & $\begin{array}{l}\text { HPLC peak } \\
\text { area }\end{array}$ & $\begin{array}{c}\text { HPLC peak } \\
\text { height }\end{array}$ \\
\hline 1-Af & $\begin{array}{l}\text { Aspergillus } \\
\text { fumigatus }\end{array}$ & positive & 36.30 & 1.12 & 311382 & 2582695 \\
\hline 2-An & Aspergillus niger & positive & 46.05 & 1.12 & 415734 & 2998531 \\
\hline $3-\mathrm{Ca}$ & Candida albicans & positive & 47.12 & 1.12 & 427253 & 2919629 \\
\hline $4-\mathrm{Ct}$ & Candida tropicalis & positive & 20.78 & 1.12 & 145277 & 3060166 \\
\hline 5-Crg & Cryptococcus gattii & positive & 46.98 & 1.12 & 425694 & 3129652 \\
\hline 6-Crn & $\begin{array}{l}\text { Cryptococcus } \\
\text { neoformans }\end{array}$ & positive & 18.61 & 1.12 & 122067 & 2656481 \\
\hline $7-\mathrm{Fs}$ & Fusarium solani & positive & 35.03 & 1.12 & 297855 & 2686931 \\
\hline 8-Mu & Mucor & positive & 34.84 & 1.12 & 235775 & 2546814 \\
\hline 9-Pe & Penicillium & positive & 44.15 & 1.12 & 395475 & 2826747 \\
\hline 10-Rh & Rhizopus & positive & 36.61 & 1.12 & 314694 & 2525958 \\
\hline $11-\mathrm{Bs}$ & Bacillus subtilis & negative & 0 & - & - & - \\
\hline $12-\mathrm{Ec}$ & Escherichia coli & negative & 0 & - & - & - \\
\hline 13-Pse & $\begin{array}{c}\text { Pseudomonas } \\
\text { aeruginosa }\end{array}$ & negative & 0 & - & - & - \\
\hline 14-Ste & $\begin{array}{c}\text { Staphylococcus } \\
\text { aureus }\end{array}$ & negative & 0 & - & - & - \\
\hline
\end{tabular}

*Chitin yield calculated per mg mycelial dry weight

$\mathrm{RT}=$ retention time
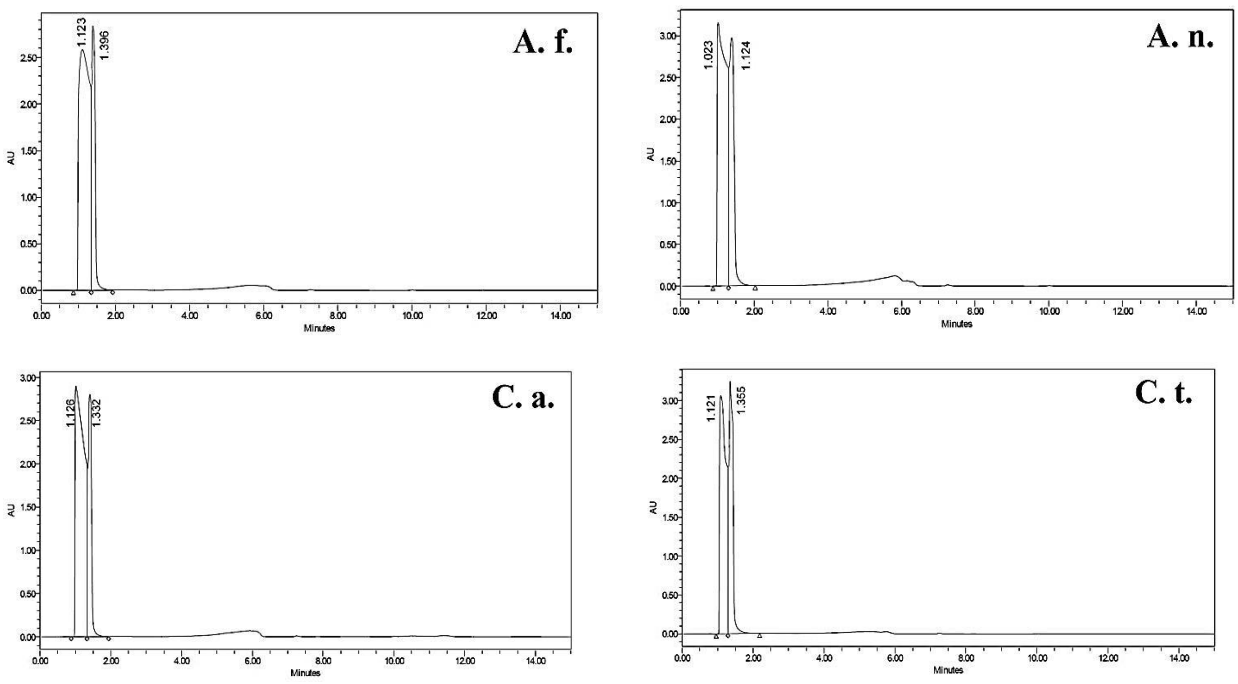

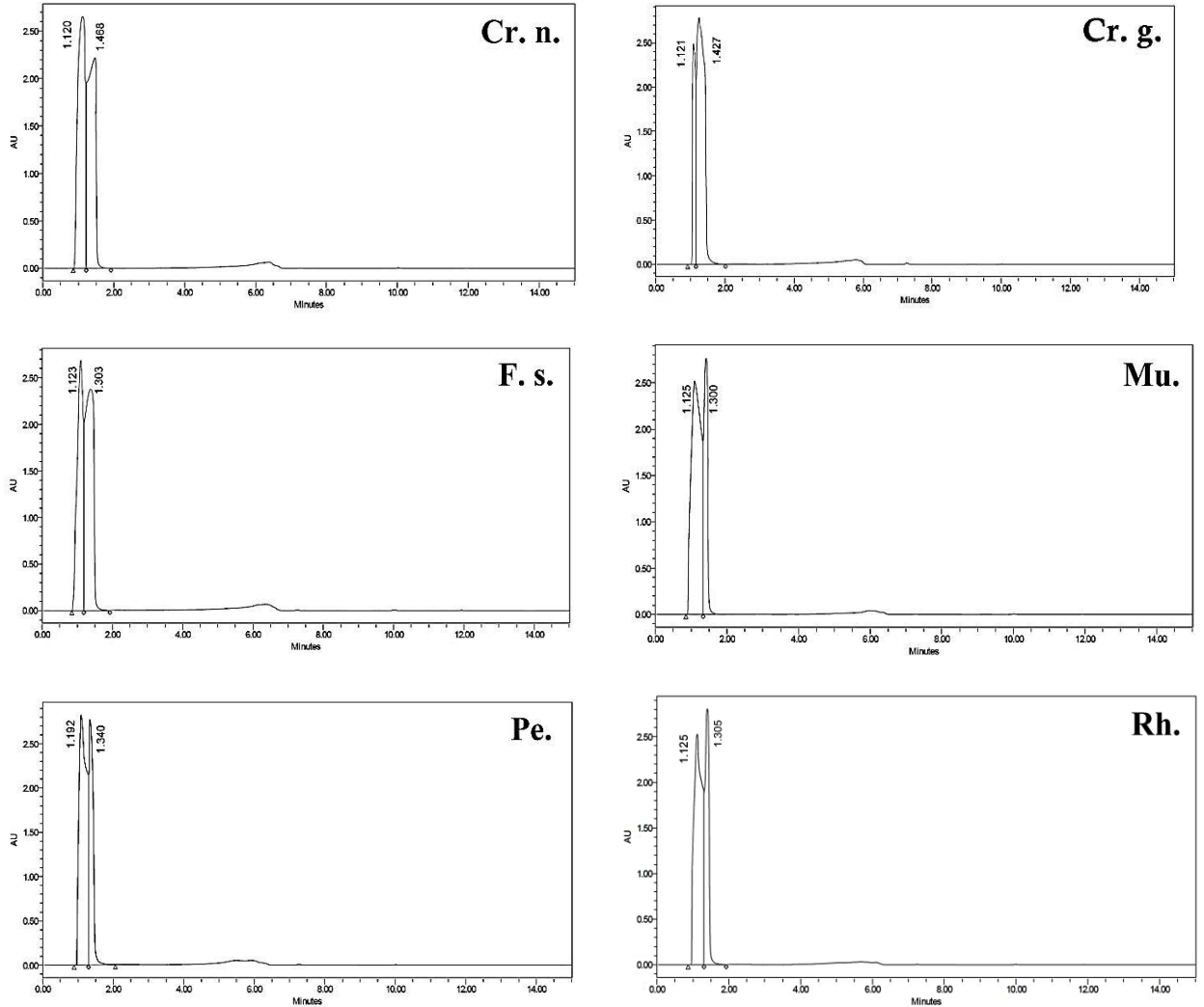

FIGURE 2. Chromatograms of chitin in pathogenic fungal isolates studied where the Y-axis is the HPLC peak height and X-axis is retention time, Af: Aspergillus fumigatus; An: Aspergillus niger; Ca: Candida albicans; Ct: Candida tropicalis; Crg: Cryptococcus gattii; Crn: Cryptococcus neoformans; Fs: Fusarium solani; Mu: Mucor sp.; Pe:

Penicillium sp.; Rh: Rhizopus sp.

The samples could be categorised into 3 groups (high, medium, low) based upon the relative amounts of chitin produced per mycelial dry weight. C. albicans, C. gattii, A. niger and Penicillium at 47.12, 46.98, 46.05, and 44.15 $\mu \mathrm{g} / \mathrm{mg}$, respectively, were placed in the high chitin content group. The medium group consisted of Rhizopus, A. fumigatus, F. solani and Mucor at 36.61, 36.30, 35.03, and $34.84 \mu \mathrm{g} / \mathrm{mg}$, respectively, while the low group consisted of C. tropicalis and C. neoformans at 20.78 and $18.61 \mu \mathrm{g} / \mathrm{mg}$, respectively. Bacterial isolates did not show any positive result for the HPLC analysis because they do not contain chitin. The bacterial isolates were included in this study to prove that false positive results from bacterial presence in clinical samples would not occur.

The chromatograms of chitin indicate that it was uniformly detected at the same retention time for all fungal isolates tested (Table 2). Two peaks were observed with retention times between 1.2 and $2 \mathrm{~min}$, similar to the chitin standard (Figure 2). The uniformity of chitin detection in fungi from different taxa is a very useful parameter in the clinical situation as a single test may be applied to detect infections caused by different fungal pathogens.

The quantity of chitin in fungi has been estimated to range from $1-2 \%$ to up to $40 \%$ of the cell wall dry weight (Munro \& Gow 2001) and varies in different fungal species or taxonomic groups (Muzarelli et al. 2011). Although chitin is essential for fungal cell viability, its role in fungal virulence is not clear (Munro \& Gow 2001), therefore, the variation in chitin quantity observed in this study may not be an indicator of the pathogenicity of the fungal species studied. However, the quantity of chitin in fungal cells may have significance when echinocandin antifungal drugs that target glucan in the cell wall are prescribed. Fungi compensate for drug induced cell wall damage by increased production of chitin to strengthen the cell wall (Walker et al. 2008). Mutant strains of C. albicans that had elevated 
levels of chitin (2-4 fold higher than reference strain) were less susceptible to caspofungin, an echinocandin drug, while a low level of chitin conferred hypersensitivity to the drug (Plaine et al. 2008). Hence, the quantity of chitin in fungal cell walls may play a role in susceptibility to caspofungin. Further studies may provide clues on whether a threshold level for chitin content in fungi correlates to caspofungin resistance.

The chitin content may be used as a convenient marker for the estimation of fungal growth in various samples (Phillips \& Gordon 1989). The synthesis of the cell wall and production of its structural components (chitin and glucan) are closely related to the plasma membrane and other membranes (Feofilova et al. 2006). These membranes contain chitin synthases and glucan synthases that construct chitin and glucans to be extruded into the cell wall space. The cell walls of pathogenic fungi such as Candida albicans, Aspergillus fumigatus, and Cryptococcus neoformans contain chitin, chitosan, $\beta$-1,3-glucan, $\beta$-1,6-glucan, mixed $\beta$-1,3-/ $\beta$-1,4-glucan, $\alpha-1,3$-glucan, melanin, and glycoproteins as major constituents (Free 2013). Although the detection of chitin cannot be used as an absolute measure of fungal biomass it may be used in comparative studies to give an indication of changes, either an increase or decrease in fungal growth (Gay 1991). Therefore, in a clinical situation, the quantitative detection of chitin in patients' samples could have both diagnostic and prognostic value.

Joergensen and Wichern (2008) concluded that chitin is the most stable biomarker to assess the total fungal contribution to microbial tissue in soil compared to ergosterol and phospholipid fatty acids. Furthermore, all true fungi contain chitin (Wallander et al. 2013) and the predominant Basidiomycetes, Ascomycetes and Zygomycetes fungal taxa contain a significant chitin concentration of $5 \%$ of dry matter (Appuhn \& Joergensen 2006). Therefore, the detection of chitin may have advantages over other biomarkers of infections currently utilized to diagnose fungal infections in clinical practice. In the clinical situation, glucan and mannan which are also components of fungal cell wall have been used as diagnostic markers of fungal infection (Arvanitis et al. 2014). Early diagnosis together with correct antifungal treatments contributes to the favorable prognosis of patients with invasive fungal infections (IFI) (Garey et al. 2006). However, current methods such as conventional microbiology often have low sensitivity for the diagnosis of IFI, thus noninvasive, non-culture-based tests are increasingly being used for faster diagnosis (Racil et al. 2010). For example, galactomannan detection is used in the diagnosis of invasive Aspergillus infections (Maertens et al. 2004, 2002), although mannan detection for diagnosis of Candida is less useful (Sendid et al. 2002). Detection of $1,3-\beta$-D-glucan (BG), a fungal-cell-wall polysaccharide, is another non-culture based method of fungal detection. In IFIs by Candida and Aspergillus, BG is released into the bloodstream which can then be detected as a biomarker. However, BG has a limited usefulness for detecting IFI caused by the Basidiomycetes fungi Cryptococcus and Zygomycetes fungi such as Rhizopus sp., both of which are important fungal pathogens (Kedzierska et al. 2007). The detection of chitin in pathogenic fungi from both these taxa (Basidiomycetes and Zygomycetes) in this study is an indication of its superiority as a potential biomarker of fungal presence compared to BG. Chitin has been detected in clinical samples obtained via surgical procedures such as brain tissue (Pisa et al. 2016) and mucin (Taylor et al. 2002) by utilizing chitin-specific proteins which bind in situ to the chitin present in fungal cells. In the fungal cell wall, chitin is linked to $\beta 1,3 / 1,6$ glucan (Latge 2007), hence, in patients with IFI, it is likely that like BG, chitin can also be detected in the bloodstream.

We have shown that chitin can be quantitatively detected in fungal pathogens from all human pathogenic taxa. The presence of chitin in humans with fungal infections needs to be explored further as it may be an alternative biomarker, especially for IFIs. Chitin may be detected in blood samples of patients in a similar way as other biomarkers such as galactomannan, mannan and $1,3-\beta$-D-glucan are detected in serum samples of patients with IFIs. The detection of chitin in clinical samples using chitin binding proteins such as chitinase (Taylor et al. 2002) or anti-chitin antibody (Pisa et al. 2016) implies that commonly used diagnostic methods such as enzyme immunoassays may be applied to detect fungal chitin in a sizable number of clinical fluid samples to evaluate the usefulness of chitin as a biomarker of fungal infections.

\section{CONCLUSION}

This study showed that the chitin content of 10 pathogenic fungal isolates from different genera and taxa was clearly detectable in all of the fungi tested. As fungal infections are on the rise and there is a need for diagnostic methods that are able to detect a range of fungi, especially those causing invasive infections, the detection of chitin may provide a sensitive and specific means for the detection of fungal presence in clinical samples.

\section{ACKNOWLEDGEMENTS}

We would like to thank Center of Desert Studies at University of Anbar, IRAQ and Universiti Teknologi Malaysia (UTM) and University Research Grant (GUP) No. Q.J130000.2545.14H56 for financial support. 


\section{REFERENCES}

Appuhn, A. \& Joergensen, R.G. 2006. Microbial colonisation of roots as a function of plant species. Soil Biology and Biochemistry 38: 1040-1051.

Arvanitis, M., Anagnostou, T., Fuchs, B.B., Caliendo, A.M. \& Mylonakis, E. 2014. Molecular and nonmolecular diagnostic methods for invasive fungal infections. Clinical Microbiology Reviews 27(3): 490-526.

Brakhage, A.A. 2005. Systemic fungal infections caused by Aspergillus species: Epidemiology, infection process and virulence determinants. Current Drug Targets 6: 875-886.

Donald, W.W. \& Mirocha, C.J. 1977. Chitin as a measure of fungal growth in stored corn and soybean seed. Cereal Chemistry 54: 466-474.

Ekblad, A. \& Nasholm, T. 1996. Determination of chitin in fungi and mycorrhizal roots by an improved HPLC analysis of glucosamine. Plant Soil 178: 29-35.

Ekblad, A., Wallander, H. \& Nasholm, T. 1998. Chitin and ergosterol combined to measure total and living fungal biomass in ectomycorrhizas. New Phytologist 138: 143-149.

Feofilova, E.P., Nemtsev, D.V., Tereshina, V.M. \& Memorskaya, A.S. 2006. Developmental change of the composition and content of the chitin-glucan complex in the kulat Aspergillus niger. Applied Biochemistry and Microbiology 42(6): 545549.

Free, S.J. 2013. Fungal cell wall organization and biosynthesis. Advances in Genetics 81: 33-82.

Garey, K.W., Rege, M., Pai, M.P., Mingo, D.E., Suda, K.J., Turpin, R.S. \& Bearden, D.T. 2006. Time to initiation of fluconazole therapy impacts mortality in patients with candidemia: A multi-institutional study. Clinical Infectious Diseases 43(1): 25-31.

Gay, L. 1991. Chitin content and chitin synthase activity as indicators of the growth of three different anaerobic rumen fungi. Federation of European Microbiological Societies Microbiology Letters 80(1): 99-102.

Joergensen, R.G. \& Wichern, F. 2008. Quantitative assessment of the fungal contribution to microbial tissue in soil. Soil Biology and Biochemistry 40(12): 2977-2991.

Kedzierska, A., Kochan, P., Pietrzyk, A. \& Kedzierska, J. 2007. Current status of fungal cell wall components in the immunodiagnostics of invasive fungal infections in humans: Galactomannan, mannan and (1A3)-b-D-glucan antigens. European Journal of Clinical Microbiology \& Infectious Diseases 26(11): 755-766.

Kim, S.K. 2013. Chitin and Chitosan Derivatives: Advances in Drug Discovery and Developments. Florida: CRC Press, Taylor \& Francis Group.

Latge, J.P. 2007. The cell wall: A carbohydrate armour for the fungal cell. Molecular Microbiology 66: 279-290.

Lin, H.H. \& Cousin, M.A. 1985. Detection of mold in processed foods by high performance liquid chromatography. Journal of Food Protection 48(8): 671-678.

Maertens, J., Theunissen, K., Verbeken, E., Lagrou, K., Verhaegen, J., Boogaerts, M. \& Eldere, J.V. 2004. Prospective clinical evaluation of lower cut-offs for galactomannan detection in adult neutropenic cancer patients and haematological stem cell transplant recipients. British Journal of Haematology 126(6): 852-860.

Maertens, J., Van Eldere, J., Verhaegen, J., Verbeken, E., Verschakelen, J. \& Boogaerts, M. 2002. Use of circulating galactomannan screening for early diagnosis of invasive aspergillosis in allogeneic stem cell transplant recipients. The Journal of Infectious Diseases 186(9): 1297-1306.

Munro, C.A. \& Gow, N.A.R. 2001. Chitin synthesis in human pathogenic fungi. Medical Mycology 39(Suppl 1): 41-53.

Muzzarelli, R.A.A., Boudrant, J., Meyer, D., Manno, N., DeMarchis, M. \& Paoletti, M.G. 2012. Current views on fungal chitin/chitosan, human chitinases, food preservation, glucans, pectins and inulin: A tribute to Henri Braconnot, precursor of the carbohydrate polymers science, on the chitin bicentennial. Carbohydrate Polymers 87(2): 9951012 .

Nandi, B. 1978. Glucosamine analysis of kulat-infected wheat as a method to determine the effect of antifungal compounds in grain preservation. Cereal Chemistry 55: 121-126.

Nilsson, K. \& Bjurman, J. 1998. Chitin as an indicator of the biomass of two wood-decay fungi in relation to temperature, incubation time, and media composition. Canadian Journal of Microbiology 44(6): 575-581.

Penman, D., Britton, G., Hardwick, K., Collin, H.A. \& Isaac, S. 2000. Chitin as a measure of biomass of Crinipellis perniciosa, causal agent of witches' broom disease of Theobroma cacao. Mycological Research 104(6): 671-675.

Pfaller, M.A. \& Diekema, D.J. 2004. Rare and emerging opportunistic fungal pathogens: Concern for resistance beyond Candida albicans and Aspergillus fumigatus. Journal of Clinical Microbiology 42(10): 4419-4431.

Phillips, M.W. \& Gordon, G.L. 1989. Growth characteristics on cellobiose of three different anaerobic fungi isolated from the ovine rumen. Journal of Antimicrobial Chemotherapy 55(7): 1695-1702.

Pisa, D., Alonso, R., Rábano, A., Horst, M.N. \& Carrasco, L. 2016. Fungal enolase, $\beta$-tubulin, and chitin are detected in brain tissue from Alzheimer's disease patients. Frontiers in Microbiology 7: 1772

Plaine, A., Walker, L., Da Costa, G., Mora-Montes, H.M., McKinnon, A., Gow, N.A.R., Gaillardin, C., Munro, C.A. \& Richard, M.L. 2008. Functional analysis of Candida albicans GPI-anchored proteins: Roles in cell wall integrity and caspofungin sensitivity. Fungal Genetics and Biology 45(10): 1404-1414.

Racil, Z., Kocmanova, I., Lengerova, M., Weinbergeroca, B., Buresova, L., Toskova, M., Winterova, J., Timilsina, S., Rodriguez, I. \& Mayer, J. 2010. Difficulties in using $1,3-b-D-$ glucan as the screening test for the early diagnosis of invasive fungal infections in patients with haematological malignancies - high frequency of false-positive results and their analysis. Journal of Medical Microbiology 59(Pt9): 1016-1022.

Richardson, M.D. 2005. Changing patterns and trends in systemic fungal infections. Journal of Antimicrobial Chemotherapy 56(Suppl 1): i5-i11.

Ride, J.P. \& Drysdale, R.B. 1972. A rapid method for the 
chemical estimation of filamentous fungi in plant tissue. Physiological Plant Pathology 2(1): 7-15.

Sendid, B., Poirot, J.L., Tabouret, M., Bonnin, A., Caillot, D., Camus, D. \& Poulain, D. 2002. Combined detection of mannanaemia and antimannan antibodies as a strategy for the diagnosis of systemic infection caused by pathogenic Candida species. Journal of Medical Microbiology 51(5): 433-442.

Taylor, M.J., Ponikau, J.U., Sherris, D.A., Kern, E.B., Gaffey, T.A., Kephart, G. \& Kita, H. 2002. Detection of fungal organisms in eosinophilic mucin using a fluorescein-labeled chitin-specific binding protein. Otolaryngology-Head and Neck Surgery 127(5): 377-383.

Tharanathan, R.N. \& Kittur, F.S. 2003. Chitin - the undisputed biomolecule of great potential. Critical Reviews in Food Science and Nutrition 43(1): 61-87.

Vallabhaneni, S., Mody, R.K., Walker, T. \& Chiller, T. 2016. The global burden of fungal diseases. Infectious Disease Clinics of North America 30(1): 1-11.

Walker, L.A., Munro, C.A., de Bruijn, I., Lenardon, M.D., McKinnon, A. \& Gow, N.A.R. 2008. Stimulation of chitin synthesis rescues Candida albicans from echinocandins. PLoS Pathogens 4(4): e1000040.

Wallander, H., Ekblad, A., Godbold, D.L., Johnson, D., Bahr, A., Baldrian, P., Bjork, R.G., Kieliszewska-Rokicka, B., Kjoller, R., Kraigher, H., Plassard, C. \& Rudawska, M. 2013. Evaluation of methods to estimate production, biomass and turnover of ectomycorrhizal mycelium in forests soils - A review. Soil Biology and Biochemistry 57: 1034-1047.

Whipps, J.M. \& Lewis, D.H. 1980. Methodology of a chitin assay. Transactions of the British Mycological Society 74(2): 416-418.

Ahmad Shehab Ahmad Lafi \& Fahrul Huyop

Department of Biotechnology and Medical Engineering

Faculty of Biosciences and Medical Engineering

Universiti Teknologi Malaysia

81310 Johor Bahru, Johor Darul Takzim

Malaysia
Ahmad Shehab Ahmad Lafi

Center of Desert Studies

University of Anbar, Ramadi

Iraq

Jacinta Santhanam*

Biomedical Science Programme

Universiti Kebangsaan Malaysia

Jalan Raja Muda Abdul Aziz

50300 Kuala Lumpur, Federal Territory

Malaysia

Tzar Mohd Nizam Khaithir

Department of Medical Microbiology and Immunology

Faculty of Medicine

Universiti Kebangsaan Malaysia Medical Centre

Jalan Yaacob Latiff

Bandar Tun Razak Cheras

56000 Kuala Lumpur, Federal Territory

Malaysia

Nur Fashya Musa

Institute of Bioproduct Development

Universiti Teknologi Malaysia

81310 Johor Bahru, Johor Darul Takzim

Malaysia

*Corresponding author; email: jacinta@ukm.edu.my

Received: 28 May 2020

Accepted: 27 August 2020 